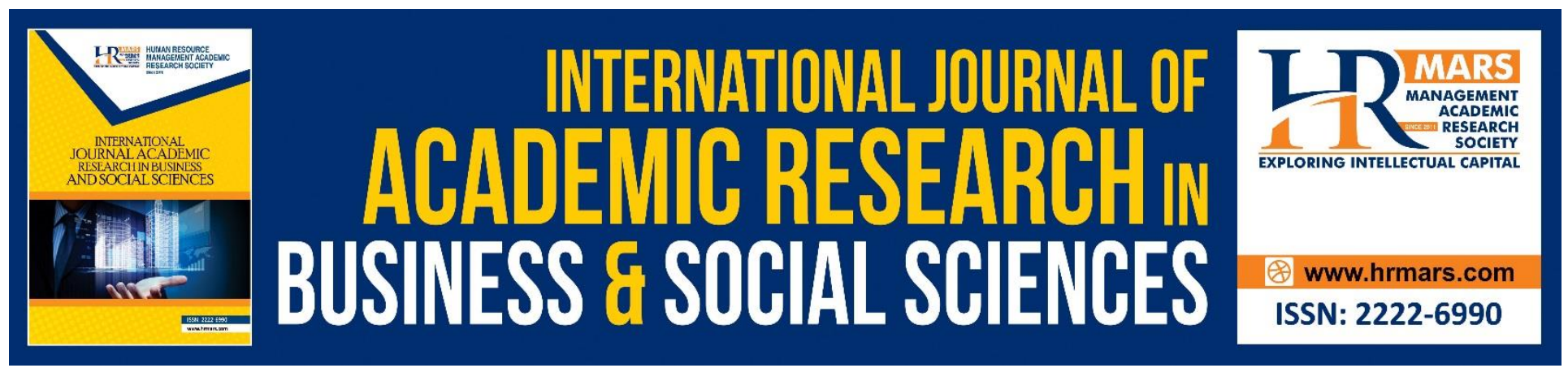

\title{
Relationship between Job Stress and Job Satisfaction among Teachers in Private and International School in Malaysia
}

\section{Heng Joe Shen, Ramli Basri, Soaib Asimiran}

To Link this Article: http://dx.doi.org/10.6007/IJARBSS/v8-i12/5012

DOI: $10.6007 /$ IJARBSS/v8-i12/5012

Received: 11 Oct 2018, Revised: 21 Nov 2018, Accepted: 12 Dec 2018

Published Online: 19 Dec 2018

In-Text Citation: (Shen, Basri, \& Asimiran, 2018)

To Cite this Article: Shen, H. J., Basri, R., \& Asimiran, S. (2018). Relationship between Job Stress and Job Satisfaction among Teachers in Private and International School in Malaysia. International Journal of Academic Research in Business and Social Sciences, 8(12), 275-286.

\section{Copyright: (c) 2018 The Author(s)}

Published by Human Resource Management Academic Research Society (www.hrmars.com)

This article is published under the Creative Commons Attribution (CC BY 4.0) license. Anyone may reproduce, distribute, translate and create derivative works of this article (for both commercial and non-commercial purposes), subject to full attribution to the original publication and authors. The full terms of this license may be seen at: http://creativecommons.org/licences/by/4.0/legalcode

Vol. 8, No. 12, 2018, Pg. 275 - 286

Full Terms \& Conditions of access and use can be found at http://hrmars.com/index.php/pages/detail/publication-ethics 


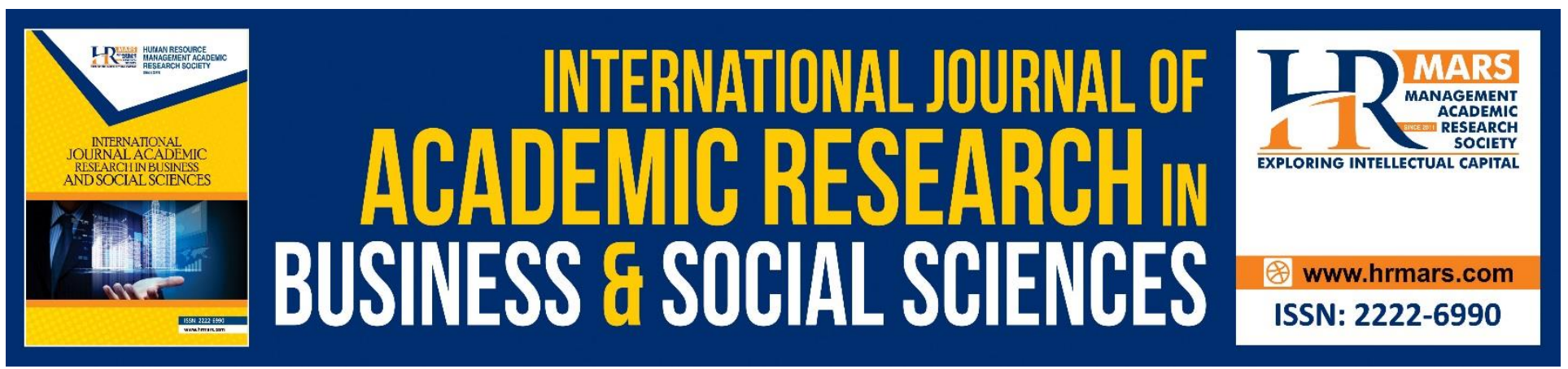

\title{
Relationship between Job Stress and Job Satisfaction among Teachers in Private and International School in Malaysia
}

\author{
Heng Joe Shen, Ramli Basri, Soaib Asimiran \\ Faculty of Educational Studies, Universiti Putra Malaysia, 43400, UPM, Serdang, Selangor Darul \\ Ehsan, Malaysia
}

\begin{abstract}
This study seeks to examine the two key variables in the school context, job stress and job satisfaction among the teachers in private and international schools. Job stress was measured through stress sources and stress manifestations while job satisfaction was measured through intrinsic factor and extrinsic factor. The participants were 249 teachers in private and international school in Selangor area. Both levels of job satisfaction and job stress were recorded at a moderate level. Results indicated statistical differences in intrinsic factors of job satisfaction and work-related stressor as well as professional distress between private and international school's teachers. Negative correlation was also found between the job stress and job satisfaction. Practical implications of the findings were discussed thoroughly to serve as guidance for the management as well as future research.
\end{abstract}

Keywords: Teacher Job Satisfaction, Job Stress, Private And International School

\section{Introduction}

Malaysia education system is comprised of national and private education system. It was reported that around $11 \%$ of the students have switch from public to private education system (KPM, 2013). Since 2012, private education has grown exponentially after the government had announced the removal of $40 \%$ quota of Malaysian students in international school (Goh, 2013). Statistically, private education using national curriculum reported about 6\% higher score in SPM than their counterparts in government schools (KPM, 2013). However, this may due to selective nature of the private education that is skewed towards population with better financial standing that could afford to pay for extra support such as personal tuition (Goh, 2013).

Student's academic achievement has always been the priority of parents. Several studies have found that academic achievement of school is among the key criteria in guiding the parents to select the ideal school for their children (Yaacob, Osman and Bachok, 2014). Currently, Malaysian student's 
academic achievement in two international assessments, PISA and TIMSS was far below the OECD average (KPM, 2013). Consequently, job satisfaction among school teacher has received much attention because several studies have shown that it affects student's performance (Michaelowa, 2002). Griffith (2004) found that job satisfaction not only positively correlated to achievement progress of student but also reduce the achievement gaps between minority and non-minority students.

Hence, in order to enhance student's performance, job stress and job satisfaction of the teachers play a crucial role. This is because teachers are the main persons that are responsible for student's performance (Michaelowa, 2002). Numerous studies have found the tremendous impact of job satisfaction on the teacher. On the flip side, job dissatisfaction among teachers would led to frustration, aggression, withdrawal behaviour such as absenteeism and turnover (Cheng, 2002; Ruzina, 2012), low organizational behaviours (Aslan, 2014), burnout (Malinen \& Savolainen, 2016) and eventually leave the teaching profession (Klassen \& Chiu, 2010; Skaalvik \& Skaalvik, 2011; Ruzina, 2012).

When teacher leave the profession, it adversely affect the school effectiveness because expertise and new ideas were required to nurture the young generation. One of the main factors affecting job satisfaction was job stress (Malinen \& Savolainen, 2016). Teacher has been reported as a profession with high level of stress (Klassen \& Chiu, 2010). Low level of job satisfaction among teachers would led to frustration, aggression, withdrawal behaviour such as absenteeism and turnover (Ruzina, 2012), low organizational behaviours (Aslan, 2014), burnout (Malinen \& Savolainen, 2016) and eventually leave the teaching profession (Skaalvik \& Skaalvik, 2011). The Star (2018, Feb 2) highlighted two cases of teachers committed suicide in Malaysia. When teacher leave the profession, it adversely affect the school effectiveness because expertise were required to nurture the young generation.

With the shortage of teachers in various subjects, there is an urgent need of studies to alleviate job stress and improve job satisfaction among teachers in Malaysia. (Bernama, 2015; Liong 2016; FMT 2016; Geryl, 2017; The Star, 2018). While studies have been conducted on these variables in other countries, Klassen, Usher and Bong (2010) found the effect of cultural factors affecting this relationship. The objective of this study is to examine job stress and job satisfaction among teachers in private and international school in Malaysia.

\section{LITERATURE REVIEW}

\section{Job Satisfaction}

Job satisfaction has been viewed from many different concepts, theories and models. Ong (2007) summarized a list of definition of job satisfaction by different authors. It has evolved from being as a form of emotion to perception and judgement. Since teacher can be slightly satisfied with specific part of their job but not satisfied with overall job, it is easier for teachers to evaluate the job rather than stating their feeling towards it. Thereupon, job satisfaction is more suitable to be studied as a construct of judgement on the job rather than an emotion. In this study, job satisfaction is described 
INTERNATIONAL JOURNAL OF ACADEMIC RESEARCH IN BUSINESS AND SOCIAL SCIENCES Vol. 8, No. 12, Dec, 2018, E-ISSN: 2222-6990 @ 2018 HRMARS

as the positive or negative evaluation of individual on their jobs (Skaalvik \& Skaalvik, 2011).

Job satisfaction also should not be confused with job motivation. Early theories such as Maslow and Alderfer depicted motivation as the attempt to fulfil satisfaction. Therefore, the sources of motivation and job satisfaction may be very similar. However, as pointed out in Porter and Lawler's motivation model (1968), there are various moderators between motivation (effort) and satisfaction such as performance and perception of the reward (satisfaction). This explains why same reward may satisfy one employee but not the other.

In the field of education, there has been attempt to identify the key variables that are related job satisfaction. Some studies indicated that there is an impact of gender on job satisfaction (Skaalvik \& Skaalvik, 2011; Tran, 2015). Ololube (2006) identified 12 sources of job satisfaction ranging from job security to working condition. Most of the past studies conducted in Malaysia separated the sources into extrinsic (hygiene) and intrinsic (motivator) (Amaranathan, 1998; Su, 1999; Jabnoun \& Yen Fook, 2001). On the other hand, studies found that job satisfaction acted as a mediating variable between job stress and withdrawal behaviour (Cheng, 2002), motivation to leave the teaching profession (Skaalvik \& Skaalvik 2011) and organizational learning and work performance (Ong, 2007). Past studies indicated negative relationship between job stress and job satisfaction (Aishah, 2004; Klassen \&Chiu, 2010; Klassen, Usher \& Bong, 2010; Tran, 2015; and Nathaniel et al., 2016).

\section{Job Stress}

In the field of education, job stress would be studied using the concept of teacher stress. Maslach \& Jackson (1984) stated teacher stress as an unpleasant feeling and emotions that came from the job. In this study, teacher stress would be described as the unpleasant negative emotions experienced by a teacher due to his inability to cope with job-related stressors (Nathaniel et al, 2016). Teacher would experience stress when he viewed the situation as threatening relative to his ability to change or improved. Given the huge impact of burnout on both personal and organizational (Thanasiritupanant, 2009), job stress is a field that is heavily studied in order to reduce burnout. Burnout is the result of prolonged high level of job stress. Kersaint (2005, in Nathaniel et al. 2016) stated that burnout is estimated to cost around 2.2 billion to 4.9 billion USD per year.

In the attempt to understand job stress, types of stressor that have been identified can range from only 4 major types by Johnstone (1989) to 20 types by Fimian (1989). There is inconsistency in the demographic factor with some studies found no significant effect of gender (Yong, 1999; Aishah, 2004; Juriani, 2007; Samad, 2010) as opposed to weak effect of gender (Klassen and Chiu, 2010; Tran, 2015). In Malaysia, Azlihanis (2009) found that prevalence of stress was $34 \%$ with $17.4 \%$ of teachers in Malaysia had mild stress and $8.5 \%$ of the teachers had severe stress. Similar study carried out by Cheng (2002) in Negri Sembilan found that 59.1\% of the teachers had moderate stress level.

\section{Private Education}

The distinct feature of private education is their independence in management and being selfsustainable. Private education comprises of both private and international section. The difference 
between them is the type of syllabus being offered. While private section utilized local or selfdeveloped syllabus, international schools source their curriculum from abroad such as America, Australia, British, Canada and India (KPM, 2013). Private section only encompasses National curriculum private school, Independent Chinese private school, religious school, special education school and correspondence school. In this study, it excludes other private centres such as tuition centre, language centre, computer learning centre and day-care centre. On the other hand, international section includes international and expatriate schools. Currently, Malaysia is among the top 6 countries with the most number of international schools as compared to other South-East Asia countries (The Star, 2017).

\section{Methodology}

In this study, a stratified random sampling of 249 teachers teaching in Selangor state was chosen in this study. This state is chosen because it had the highest number of private and international schools in Malaysia as compared to other states (KPM, 2017). The ratio of teachers working in private school as compared to international school was 1.45: 1.00 because the number of schools as well as the number of teachers working in private schools is more than double the number of teachers working in international schools. The questionnaire comprised of four sections: demographic, sources of concern, manifestations of stress and job satisfaction.

Sources of concern and manifestation of stress were measured with Teacher Stress Inventory (TSI) developed by Fimian (1984, in Fimian, 1988). Fimian (1988) suggested naming it as "sources of concern" instead of "sources of stress" in the questionnaire to avoid sensitization of teacher stress. Unlike western countries, Malaysian teachers especially whom are Muslim are forbidden to consume alcohol. Thus, the item "by using alcohol" was removed because it was irrelevant and might lead to biasness where stressful teacher could display strong behavioural manifestation without consuming alcohol. In order to prevent confusion, the word "drugs" was changed to "medicine". All items have 5-point Likert scale, anchored by 1 (strongly disagree) and 5 (strongly agree).

Job satisfaction was measured with Minnesota Satisfaction Questionnaire (MSQ) developed by Weiss, Dawis and England (1967). It had a 5-point Likert scale, anchored by 1 (very dissatisfied) and 5 (very satisfied). The data collection follows a formal procedure to ensure that the management in the school was aware of the research being carried out. This study employed both online and printed questionnaire. Participant would be informed of the two months grace period in filling the

questionnaire. Descriptive statistics, independent t-test and Pearson correlation were employed to analyze the data.

\section{Results}

There were 147 teachers from private school and 102 teachers from international school. Out from 249 teachers, less than a quarter (21.29\%) was male. There were only 42 male teachers in private school and 11 male teachers in international school. Majority of the teachers were still single (59.44\%), followed by married (36.95\%) and a small percentage of teachers who was divorced (3.61\%). In terms of ethnic, the dominant races were Chinese (46.18\%) and Indian (34.54\%) followed 
INTERNATIONAL JOURNAL OF ACADEMIC RESEARCH IN BUSINESS AND SOCIAL SCIENCES Vol. 8, No. 12, Dec, 2018, E-ISSN: 2222-6990 C 2018 HRMARS

by Malay (15.66\%) and others (3.61\%). Most of the teachers had the highest qualification of Degree (69.08\%), followed by Masters (21.29\%) and others (9.64\%). The mean age of the teachers was 34.67 with standard deviation of 7.69 while mean years of teaching was 8.04 years with standard deviation of 6.14. The mean socioeconomic status of the students was 3.73 and none of the teachers indicate the score below 3 .

Comparison between the mean score of job satisfaction between those teachers in private and international was shown in Table 1. This study found that teachers in international school had statistically significantly higher level of job satisfaction (3.396 \pm 0.630$)$ compared to teachers in private school $(3.230 \pm 0.497)$ where $t_{247}=-2.224, p=.027$. Comparison between the dimensions found that the intrinsic factor was statistically significant but extrinsic factor did not.

Table 1: Comparison on Level of Job Satisfaction between Private and International

\begin{tabular}{lllllll}
\hline & \multicolumn{7}{l}{ Private } & \multicolumn{7}{l}{ International } \\
\cline { 2 - 7 } Dimension & Mean & SD & Mean & SD & t & p-value \\
\hline Intrinsic & 3.298 & 0.513 & 3.502 & 0.618 & -2.847 & $.005^{* *}$ \\
Extrinsic & 3.078 & 0.638 & 3.203 & 0.873 & -1.229 & .221 \\
Job satisfaction & 3.230 & 0.497 & 3.396 & 0.630 & -2.224 & $.027^{*}$ \\
\hline
\end{tabular}

*Significant difference at $p<.05$ and $* *$ significant difference at $p<.01$

Comparison between the mean score of job stress between those teachers in private and international was shown in Table 2. There was also statistically significantly lower level of job stress among teachers in international school $(2.621 \pm 0.628)$ compared to teachers in private school $(2.785$ \pm 0.553 ) where $t_{247}=2.180, p=.030$. When each factor of the dimensions was compared, it was found that work-related stressor and professional distress were the contributing factors to the difference in job stress level between teachers from private and international. In fact, the mean score in workrelated stressor and professional distress were the highest among private school teachers as compare to all other factors. 
INTERNATIONAL JOURNAL OF ACADEMIC RESEARCH IN BUSINESS AND SOCIAL SCIENCES Vol. 8, No. 12, Dec, 2018, E-ISSN: 2222-6990 @ 2018 HRMARS

Table 2: Comparison on Level of Job Stress between Private and International

\begin{tabular}{|c|c|c|c|c|c|c|}
\hline \multirow[b]{2}{*}{ Dimension and Factor } & \multicolumn{2}{|c|}{ Private } & \multicolumn{3}{|c|}{ International } & \multirow[b]{2}{*}{ p-value } \\
\hline & Mean & SD & Mean & SD & $t$ & \\
\hline Sources of stress & 3.240 & 0.496 & 3.027 & 2.215 & $\begin{array}{l}2.64 \\
7\end{array}$ & $.009 * *$ \\
\hline Time management & 3.304 & 0.517 & 3.207 & 0.486 & $\begin{array}{l}1.48 \\
3\end{array}$ & .139 \\
\hline Work-related stressor & 3.456 & 0.551 & 3.160 & 0.788 & $\begin{array}{l}3.27 \\
3\end{array}$ & $.001 * *$ \\
\hline Professional distress & 3.306 & 0.654 & 2.943 & 1.048 & $\begin{array}{l}3.10 \\
5\end{array}$ & $.002 * *$ \\
\hline Discipline and motivation & 3.167 & 0.783 & 3.051 & 0.994 & .985 & .326 \\
\hline Professional investment & 2.969 & 0.741 & 2.772 & 0.971 & $\begin{array}{l}1.73 \\
2\end{array}$ & .085 \\
\hline Manifestations of stress & 2.330 & 0.776 & 2.215 & 0.730 & $\begin{array}{l}1.17 \\
5\end{array}$ & .241 \\
\hline Emotional & 2.710 & 0.944 & 2.614 & 0.953 & .790 & .430 \\
\hline Fatigue & 2.722 & 0.804 & 2.663 & 0.825 & .570 & .569 \\
\hline Cardiovascular & 2.347 & 1.090 & 2.193 & 1.001 & $\begin{array}{l}1.13 \\
5\end{array}$ & .258 \\
\hline Gastronomic & 2.048 & 1.114 & 1.856 & 0.956 & $\begin{array}{l}1.41 \\
1\end{array}$ & .159 \\
\hline Behavioural & 1.823 & 0.904 & 1.752 & 0.951 & .601 & .549 \\
\hline Job stress & 2.785 & 0.553 & 2.621 & 0.628 & $\begin{array}{l}2.18 \\
0\end{array}$ & $.030 *$ \\
\hline
\end{tabular}

*Significant difference at $p<.05$ and ** significant difference at $p<.01$

There was a small and definite negative correlation between the two research variables $(r=-.318, p$ $=.000$ ) as shown in Table 3. There was also observable negative correlation between each dimensions of job stress and job satisfaction with exception for the correlation between manifestations of stress with extrinsic factor. The strongest correlation was found between sources of stress and job satisfaction $(r=-.460, p=.000)$.

Table 3: Pearson's Correlation between Job Stress and Job Satisfaction Dimensions

\begin{tabular}{lllll}
\hline & Variables & Intrinsic & Extrinsic & Job satisfaction \\
\hline 1 & Sources of stress & $-.373^{* *}$ & $-.429^{* *}$ & $-.460^{* *}$ \\
2 & Manifestations of stress & $-.126^{*}$ & -.092 & $-.131^{*}$ \\
3 & Job stress & $-.271^{* *}$ & $-.276^{* *}$ & $-.318^{* *}$ \\
\hline
\end{tabular}

*Significant difference at $\mathrm{p}<.05$ and ${ }^{* *}$ significant difference at $\mathrm{p}<.01$ 
INTERNATIONAL JOURNAL OF ACADEMIC RESEARCH IN BUSINESS AND SOCIAL SCIENCES

Vol. 8, No. 12, Dec, 2018, E-ISSN: 2222-6990 @ 2018 HRMARS

\section{Discussion}

Comparison between private and international school teachers found that international school teacher had higher level of job satisfaction. This could be explained based on the level of autonomy in the school. In private school such as Chinese Independent School, the class size is normally above 30 students per class for it to be sustainable. Alternatively, international school can have lower class size by charging higher fees (school advisor, 2015). Chinese Independent School usually charges below RM6000 per annum while international school charges triple that amount. With smaller class size, teachers in international school have higher autonomy in carrying out their teaching effectively. In some international schools, there is even teaching assistant to support the teaching.

On the other hand, the level of job satisfaction was lowest in teacher's salary. The Star (2015, June 8) had reported that teacher's salary was an important factor for staff retention. Private schools constantly provide competitive salary in order to woo the best teachers. Nonetheless, numerous studies had pointed out to the increasing workload of the teachers that came from tremendous paperwork, meeting with teachers or parents, coping with changes in curriculum and running of school projects (Skaalvik \& Skaalvik, 2011). There is a perceived inequity of their reward or the salary that they received based on the huge workload.

International school teachers also had lower level of job stress, especially in work-related stressor and professional distress. Work-related stressor came from the amount of work including administrative paperwork while professional distress came from rewards and recognition. As expected, this study found that inadequate salary had the highest mean score among the items in professional distress. This was expected because private school that adopted National syllabus, there was too much emphasis on the high-stakes examination (Supramaniam \& Nazer, 2016). This additional paperwork directly contributed to the work-related stressors of the teachers in private school.

There is a possibility that the distinctive cultural difference between private and international school played a role here. Low (2015) suggested that cultural differences were manifested in the general language usage, learning environment and the practice of cultural values. International school that uses English as the medium of instruction would have very different culture than private school. In addition, international school has foreign teachers as well as foreign students. The mix of different races allows different culture to interact that resulted in different school culture.

This study found definite but small correlation between job stress and job satisfaction and substantial relationship between sources of stress and job satisfaction. Some studies indicated that there were several mediating variables in the relationship such as burnout and self-efficacy (Skaalvik \& Skaalvik, 2009; Klassen \& Chiu, 2010). Recent studies had put the emphasis on reducing job stress as a way to improve job satisfaction instead. This could be done by strengthening teachers' self-efficacy (Caprara et al., 2006; Klassen \& Chiu, 2010; Viel-Ruma et al. 2010; Stephanou, Gkavras \& Doulkeridou, 2013; Tran, 2015 and Malinen \& Savolainen, 2016). Self-efficacy is the teacher's self-assessment on their capabilities. Higher self-efficacy would reflect better coping mechanism by the teachers. Klassen \& Chiu (2010) had ascertained that classroom management self-efficacy and instructional strategies 
INTERNATIONAL JOURNAL OF ACADEMIC RESEARCH IN BUSINESS AND SOCIAL SCIENCES

Vol. 8, No. 12, Dec, 2018, E-ISSN: 2222-6990 @ 2018 HRMARS

self-efficacy had direct correlation with job satisfaction.

\section{Practical Implications}

This study had identified important factor that contributed to job satisfaction and job stress. Although the common factor was inadequate salary of the teachers, it was impractical to continuously increase teacher's salary. Experimental study by Yuan et al. (2013) had also highlighted the failure in implementing incentive pay programs where students' performance was the indicator. This was because teacher's had doubt on their ability to influence students' performance when there were other influential variables such as student's socioeconomic status, parental expectation and parental involvement in student's educational process. It also found that teachers perceived the extra allowance as acknowledgement of their hard work and not motivation to improve. Thereupon, increasing the pay was clearly not a way forward.

Nevertheless, continuous professional development (CPD) for teachers is crucial to develop selfefficacy (Tran, 2015). There should be comprehensive CPD that includes classroom management, effective student engagement as well as effective instructional strategies. It should also tailor for diverse demographic groups of teachers. This would allow teachers to learn at their pace and explore different content based on their needs. This would be possible by adopting e-learning in the CPD. Examples of such practices has been observed in Cambridge English Webinars that provide regular online tips on teaching and learning. Recordings are also made available for those interested teachers for revision purposes.

Significant differences on the level of job satisfaction and job stress between private and international school teachers would discern that these differences come from the autonomy of the teachers, disparity in syllabus and possible effect of culture. In elevating teacher's autonomy, this could come from systematic changes to the school structure. Skaalvik \& Skaalvik (2007) suggested that teachers ought to be given the choice to use their best teaching and learning methods. Management needs to understand the effect of individualization rather than standardization in the teaching methods of all teachers.

The disparity in the syllabus as pointed out by Supramaniam \& Nazer (2016) should also serve as a reference for better curriculum development in the future. Study by Yaacob, Osman and Bachok (2014) had shown that syllabus was the key driving force for parents to enrol their kids in private and international school. Parents often felt that there is a better integration of extra curriculum in the international school syllabus (Melissa, 2013). Besides the common academic achievement, parents now also demand for other types of learning such as character building and non-academic subjects such as music, swimming and robotic.

\section{Conclusion}

This study investigated the relationship between job stress and job satisfaction in the context of private and international schools. While the level of job satisfaction and job stress were found to be at moderate level, statistical differences have been observed in several factors between private and 
INTERNATIONAL JOURNAL OF ACADEMIC RESEARCH IN BUSINESS AND SOCIAL SCIENCES Vol. 8, No. 12, Dec, 2018, E-ISSN: 2222-6990 @ 2018 HRMARS

international school teachers. Elaborate discussion on these differences would be helpful for the schools to learn from one another. Correlation between these two variables provides further evidence on the substantial relationship that the management could work on. It is hopeful that more study would be conducted in this area especially between public and private sector.

\section{References}

Aishah, B. A. T. (2004). Kepuasan kerja dan tekanan yang dihadapi oleh guru sekolah menengah (Unpublished master's project paper). University Putra Malaysia, Selangor.

Amaranathan, S. (1998). Factors relating to job satisfaction of secondary school teachers in the district of balakong (Unpublished master's project paper). University Putra Malaysia, Selangor.

Aslan, A. S., Shaukat, M. Z., Ahmed, I., Shah, I. M., \& Mahfar, M. (2014).Job satisfactions of academics in Malaysian public universities. Procedia-Social and Behavioral Sciences, 114, 154-158.

Azlihanis, A. H., Nyi, N. N., Aziah, D., Rusli, N., \& Mohd, R. S. (2009). Prevalence and factors associated with stress among secondary school teachers in Kota Bharu, Kelantan, Malaysia. Southeast Asian Journal of Tropical Medicine and Public Health, 40(6), 1359-1370.

Bernama (2015, December 10). Retirees to help overcome English teacher shortage. Free Malaysia Today. Retrieve online from http://www.freemalaysiatoday.com/category/nation/2015/12/10/retirees-to-help-overcomeenglish-teacher-shortage/

Caprara, G. V., Barbaranelli, C., Steca, P., \& Malone, P. S. (2006). Teachers' self-efficacy beliefs as determinants of job satisfaction and students' academic achievement: A study at the school level. Journal of school psychology, 44(6), 473-490.

Cheng, F.K. (2002). Occupational stress, organizational commitment, career commitment, job satisfaction and withdrawal cognition among school teachers (Unpublished doctoral dissertation). University Putra Malaysia, Malaysia.

Fimian, M. (1988). Teacher stress inventory. Clinical psychology publishing.

Geryl, O (2017, January 27). Quick fix to solve teacher's shortage. The Star. Retrieved online from https://www.thestar.com.my/metro/community/2017/01/27/quick-fix-to-solve-teachersshortage-sarawak-graduates-from-other-fields-urged-to-fill-up-988-teachi/

Goh, L. (2013, August 11). Million ringgit schooling. The Star. Retrieved online from http://www.thestar.com.my/opinion/columnists/commonsense/2013/08/11/million-ringgitschooling/

Griffith, J. (2004). Relation of principal transformational leadership to school staff job satisfaction, staff turnover, and school performance. Journal of Educational Administration, 42(3), 333-356.

Jabnoun, N., \& Yen Fook, C. (2001). Job satisfaction of secondary school teachers in Selangor, Malaysia. International Journal of Commerce and Management, 11(3/4), 72-90.

Johnstone, M. (1989). Stress in Teaching. An Overview of Research. Scottish Council for Research in Education, 15 St. John Street, Edinburgh, Scotland EH8 8JR (L4. 20).

Juriani, B. J. (2007). Stressors and stress levels of primary school music teachers in Selangor, Malaysia (Unpublished master's thesis). University Putra Malaysia, Selangor.

Klassen, R. M., \& Chiu, M. M. (2010). Effects on teachers' self-efficacy and job satisfaction: Teacher gender, years of experience, and job stress. Journal of educational Psychology, 102(3), 741. 
INTERNATIONAL JOURNAL OF ACADEMIC RESEARCH IN BUSINESS AND SOCIAL SCIENCES

Vol. 8, No. 12, Dec, 2018, E-ISSN: 2222-6990 @ 2018 HRMARS

Klassen, R. M., Usher, E. L., \& Bong, M. (2010). Teachers' collective efficacy, job satisfaction, and job stress in cross-cultural context. The Journal of Experimental Education, 78(4), 464-486.

KPM (2013). Blueprint 2013-2025. Ministry of Education, Malaysia.

KPM (2017). Malaysia Educational Statistics 2017. Ministry of Education, Malaysia.

Liong, K. C. (2016, February 23). Perennial shortage of Chinese teachers. The Star. Retrieved online from http://www.thestar.com.my/opinion/letters/2016/02/23/perennial-shortage-ofchinese-teachers/

Low, M. J. (2015). Chinese private schools as a viable route to secondary education in Malaysia: A case study. Malaysian Journal of Chinese Studies, 4(2): 45-59

Malinen, O. P., \& Savolainen, H. (2016). The effect of perceived school climate and teacher efficacy in behavior management on job satisfaction and burnout: A longitudinal study. Teaching and Teacher Education, 60, 144-152.

Melissa, C. (2014, May 20). What price, international school education? Malay mail online. Retrieved from http://www.themalaymailonline.com/malaysia/article/what-price-international-schooleducation\#6lyZApGDBUIrcUDi.97

Michaelowa, K. (2002). Teacher job satisfaction, student achievement, and the cost of primary education in Francophone Sub-Saharan Africa (No. 188). HWWA Discussion Paper.

Nathaniel, P., Sandilos, L. E., Pendergast, L., \& Mankin, A. (2016). Teacher stress, teaching-efficacy, and job satisfaction in response to test-based educational accountability policies. Learning and Individual Differences, 50, 308-317.

Ololube, N. P. (2006). Teachers Job Satisfaction and Motivation for School Effectiveness: An Assessment. Online Submission.

Ong, G. P. (2007). The effect of organizational learning on organizational commitment, job satisfaction and work performance (Unpublished doctoral dissertation). University Putra Malaysia, Malaysia.

Ruzina, J. (2012). Job satisfaction of new teachers in Malaysia: Understanding challenges and experiences of leaving the profession (Doctoral dissertation). Colorado State University, United States.

Samad, N. I. A., Hashim, Z., Moin, S., \& Abdullah, H. (2010). Assessment of stress and its risk factors among primary school teachers in the Klang Valley, Malaysia. Global Journal of Health Science, 2(2), 163.

Skaalvik, E. M., \& Skaalvik, S. (2007). Dimensions of teacher self-efficacy and relations with strain factors, perceived collective teacher efficacy, and teacher burnout. Journal of educational psychology, 99(3), 611.

Skaalvik, E. M., \& Skaalvik, S. (2011). Teacher job satisfaction and motivation to leave the teaching profession: Relations with school context, feeling of belonging, and emotional exhaustion. Teaching and teacher education, 27(6), 1029-1038.

Stephanou, G., Gkavras, G., \& Doulkeridou, M. (2013). The role of teachers' self- and collectiveefficacy beliefs on their job satisfaction and experienced emotions in school.Psychology, 4(03), 268. 
INTERNATIONAL JOURNAL OF ACADEMIC RESEARCH IN BUSINESS AND SOCIAL SCIENCES Vol. 8, No. 12, Dec, 2018, E-ISSN: 2222-6990 C 2018 HRMARS

Su, C. H. (1999). Factors influencing job satisfaction of government secondary school teachers in the district of Petaling, Selangor (Unpublished master's project paper). University Putra Malaysia, Malaysia.

Supramaniam, K., \& Nazer, A. (2016). Two rabbits in a hat: Comparison of SPM English language and IGCSE English as second language high-stakes test. National Conference of Research on Language Education 2016.

Thanasiritupanant, N. (2009). Strategies for coping with stressful situations (Doctoral dissertation). Thammasat University Bangkok, Thailand.

The Star (2015, June 28). The Star. Wooing teachers. Retrieved online from https://www.thestar.com.my/news/education/2015/06/28/wooing-teachers/

The Star (2017, March 12). Malaysia, in top 10 list with most international schools. The Star. Retrieved online from http://www.thestar.com.my/news/education/2017/03/12/malaysia-in-top-10list-with-most-international-schools/

The Star (2018, Feb 2). 'Don't speculate on death of teachers'. The Star. Retrieved online from https://www.thestar.com.my/news/nation/2018/02/02/dont-speculate-on-death-ofteachers-chong-let-education-dept-complete-probe/

School advisor (2015, Oct 26). Tuition fees for Year 7 International schools in Klang Valley. Times Online Media. Retrieved online from https://schooladvisor.my/mkini-articles/tuition-fees-foryear-7-international-schools-in-klang-valley/

Tran, V. D. (2015). Effects of gender on teachers' perceptions of school environment, teaching efficacy, stress and job satisfaction. International Journal of Higher Education, 4(4), 147.

Viel-Ruma, K., Houchins, D., Jolivette, K., \& Benson, G. (2010). Efficacy beliefs of special educators: The relationships among collective efficacy, teacher self-efficacy, and job satisfaction. Teacher Education and Special Education, 33(3), 225-233.

Welford, A. T. (1973). Stress and performance. Ergonomics, 16(5), 567-580.

Yaacob, N. A., Osman, M. M., \& Bachok, S. (2014). Factors influencing parents' decision in choosing private schools. Procedia-Social and Behavioral Sciences, 153, 242-253.

Yong, I. T. (1999). Factors affecting occupational stress among teachers of a secondary school in Sarawak (Unpublished master's project paper).University Putra Malaysia, Malaysia.

Yuan, K., Le, V. N., McCaffrey, D. F., Marsh, J. A., Hamilton, L. S., Stecher, B. M., \& Springer, M.

G. (2013). Incentive pay programs do not affect teacher motivation or reported practices: Results from three randomized studies. Educational Evaluation and Policy Analysis, 35(1), 3-22. 